\title{
Study on Solid Phase Extraction and Spectrophotometric Determination of Vanadium with 2-(2-Quinolylazo)-5-Diethylaminophenol
}

\author{
Qiufen Hu, ${ }^{\dagger+*}$ Guangyu Yang, ${ }^{+\bullet}$ Zhangjie Huang, and Jiayuan Yin ${ }^{\dagger}$ \\ 'Department of Chemistrv. Iunnan Lniversitv. Kumming 650091. P.R. China \\ -Department of Chemistry, Yuxi Teacher's College, Yuxi 653100. P.R. China \\ Received October 10.2003
}

\begin{abstract}
A sensitive. selective and rapid method has been developed for the determination $\mu \mathrm{g} / \mathrm{L}$ level of vanadium ion based on the rapid reaction of vanadium(V) with 2-(2-quinolylazo)-5-diethylaminophenol (QADEAP) and the solid phase extraction of the colored chelate with $\mathrm{C}_{18}$ cartridge. The QADEAP reacts with $\mathrm{V}(\mathrm{V})$ in the presence of citric acid-sodium hydroxide buffer solution $(\mathrm{pH}=3.5)$ and cetyl trimethylammonium bromide (CTMAB) medium to form a violet chelate of a molar ratio $1: 2$ (V(V) to QADEAP). This chelate was enriched by solid phase extraction with $\mathrm{C}_{18}$ cartridge and the enrichment factor of 50 was obtained by elution of the chelates from the cartridge with ethanol. The molar absorptivity of the chelate is $1.28 \times 10^{5} \mathrm{~L} \mathrm{~mol}^{-1} \mathrm{~cm}^{-1}$ at $590 \mathrm{~nm}$ in the measured solution. Beer's law is obeyed in the range of $0.01-0.6 \mu \mathrm{g} / \mathrm{mL}$. The detection limit is $0.04 \mu \mathrm{g} / \mathrm{L}$ in the original samples. This method was applied to the determination of vanadium $(V)$ in water and biological samples with good results.
\end{abstract}

Key Words : 2-(2-Quinolylazo)-5-diethylaminophenol, Vanadium, Spectrophotometry, Solid phase extraction

\section{Introduction}

Vanadium is an important element. not only for industry: but for biological sy'stems as well. 1.: Therefore a wide variety of spectrophotometric methods for the determination of vanadium have been reported. ${ }^{3-11}$ Each chromogenic system has its advantages and disadvantages with respect to sensitivity. selectivity and rapidity. In previous work some 2-quinolylazo reagents were reported for the determination of metal ions. ${ }^{12-16}$ This type of reagent has higher sensitivity than pyridy lazo reagents because of its larger conjugated system. However. the utilization of 2-quinolylazo reagents for the determination of sanadium has not been reported yet. In this paper. we firstly studied the color reaction of QADEAP with vanadium( $(\mathrm{V})$ and the solid phase extraction of the colored chelate with $\mathrm{C}_{18}$ cartridge. Based on this. a highly sensitive. selective and rapid method for the determination of vanadium in water and biological samples was developed.

\section{Experimental Section}

Apparatus. A UV-160A spectrophotometer (Shimidzu. Japanese) equipped with a $1 \mathrm{~cm}$ microcell $(0.5 \mathrm{~mL})$ was used for all absorbance measurements. The $\mathrm{pH}$ values were determined with a Beckman $\Phi-200 \mathrm{pH}$ meter. The extraction was performed on a Waters Solid Phase Extraction (SPE) Device (It is able to prepare twenty samples simultaneously). and Waters Sep-Pak $C_{18}$ cartridge (1 cc/30 mg. $30 \mu \mathrm{m}$ ) (Waters corporation. USA) was used in this Experiment.

\footnotetext{
"To whom corespondence should be addressed. Fax: +86-8718316812; e-mail: huqufenata $163 . \mathrm{con}$
}

Chemicals. All of the solutions were prepared with ultrapure water obtained by a Milli-Q50 SP Reagent Water System (Millipore Corporation. USA). High purity ethanol (Fisher Corporation. USA) was used. QADEAP was synthesized by our laboratory as following procedure: 2aminoquinoline $(6.9 \mathrm{~g}: 0.048 \mathrm{~mol}$ ) was dissolved in $500 \mathrm{~mL}$ anhydrous ethanol. To which. sodamide ( $2.0 \mathrm{~g}: 0.051 \mathrm{~mol}$ ) was added and the mixture was refluxed in boiling water bath for $5 \mathrm{~h}$, followed by the addition of isoamyl nitrite ( 7.4 $\mathrm{mL}$ ). The solution was refluxed for $30 \mathrm{~min}$ with boiling water bath. then the solution was cooled and placed over night under $0^{\circ} \mathrm{C}$. The diazo salt was obtained by filtering this solution with an isolation yield of $92 \%$. The diazo salt was dissolved in $200 \mathrm{~mL}$ anlydrous ethanol. followed by the addition of $m$-dietlylaminophenol (6.6 g: $0.042 \mathrm{~mol}$ ). The carbon dioxide was ventilated into the solution with stirring until the $\mathrm{pH}$ reaches to about 8.0. The solution stood for two days. then diluted the solution with $400 \mathrm{~mL}$ water and extracted with chloroform. The chloroform was evaporated and the residue was re-crystallized with $30 \%$ ethanol. The QADEAP was obtained with a yield of $28 \%$. The structure of QADEAP was verified by elemental analysis. IR. ${ }^{\mathrm{H}} \mathrm{H}$ NMR and MS. Elemental analysis: $\mathrm{C}_{19} \mathrm{H}_{20} \mathrm{~N}_{4} \mathrm{O}$ found (calculated) C 71.06 (71.23), N 17.13 (17.49), H 6.47 (6.29). IR $(\mathrm{KBr})\left(\mathrm{cm}^{-1}\right): 3610\left(v_{-O H}\right): 1050\left(v_{-C_{O}}\right): 1615,1570$. 1510. $1420\left(v_{C=C \ldots}-\mathrm{Y}=\mathrm{K}-\right): 1375.1326\left(v_{\mathrm{CK}}\right): 2920.2873$ $\left(v_{C-\mathrm{H}}\right): 1465,1380\left(\delta_{\mathrm{CH}}\right): 3070,3016\left(\sigma_{\mathrm{A}-\mathrm{H}}\right): 1175,1120$. 865. 775. $730\left(\delta_{\mathrm{A}-\mathrm{H}}\right) .{ }^{1} \mathrm{H}$ NMR (solvent: $\mathrm{d}_{\delta}$-acetone) $(\delta$ ppm): $1.25\left(\mathrm{t} 6 \mathrm{H}, \mathrm{C}-\mathrm{CH}_{3}\right): 2.75\left(\mathrm{q} 4 \mathrm{H} . \mathrm{N}-\mathrm{CH}_{2}-\right) .2 .25(\mathrm{~s} 1 \mathrm{H}$. $-\mathrm{OH}): 6.86-7.85(\mathrm{~m} 9 \mathrm{H}, \mathrm{Ar}-\mathrm{H})$. MS: $320\left(\mathrm{M}^{+}\right)$.

A $1.0 \times 10^{-4} \mathrm{~mol} / \mathrm{L}$ of QADEAP solution was prepared by dissolving QADEAP with 95\% ethanol. A stock standard solution of vanadium $(1.0 \mathrm{mg} / \mathrm{mL})$ was obtained from 
Chinese Standard Center, and a work solution of $0.2 \mu \mathrm{g} / \mathrm{ml}$. was prepared by diluting this solution. Citric acid-sodium hydroxide buffer solution $(0.5 \mathrm{~mol} / \mathrm{L}, \mathrm{pH}=3.5$ (containing $0.1 \mathrm{~mol} / \mathrm{L} . \mathrm{Na} 2 \mathrm{CDTA}$ and $\left.0.5 \mathrm{~mol} / 1 . \mathrm{NH}_{4} \mathrm{~F}\right)$ ) was prepared by dissolving $86 \mathrm{~g}$ of citric acid $\left(\mathrm{C}_{6} \mathrm{H}_{8} \mathrm{O}_{7}\right), 32.7 \mathrm{~g}$ of ethylenediamine tetraacetic acid disodium salt $\left(\mathrm{C}_{10} \mathrm{H}_{14} \mathrm{~N}_{2} \mathrm{Na}_{2} \mathrm{O}_{8} \cdot 2 \mathrm{H}_{2} \mathrm{O}\right)$ and $20.5 \mathrm{~g} \mathrm{NH}_{4} \mathrm{~F}$ in $600 \mathrm{ml}$, of water, then the solution was neutralized to $\mathrm{pH} 3.5$ with $20 \%$ sodium hydroxide, and diluted to the volume of $1000 \mathrm{ml}$.. Cetyl trimethylammonium bromide (CTMAB) solution $(1.0 \%(w / v))$ was prepared by dissolving CTMAB with $20 \%$ ethonal, All chemical used were of analytical grade unless otherwise stated.

Standard procedure. To a standard or sample solution containing no more than $1.2 \mu \mathrm{g}$ of $\mathrm{V}(\mathrm{V})$ in a $100 \mathrm{ml}$. of calibrated flask, $5 \mathrm{ml}$, of citric acid-sodium hydroxide buffer solution (containing $0.1 \mathrm{~mol} / \mathrm{l}, \mathrm{Na} 2$ Г.DTA and $0.5 \mathrm{~mol} / \mathrm{L}$. $\left.\mathrm{NH}_{4} \mathrm{~F}\right), 5.0 \mathrm{~mL}$ of $1.0 \times 10^{-1} \mathrm{~mol} / 1$. QADГ.AP solution and $3.0 \mathrm{~mL}$ of $1.0 \%$ CTMAB solution were added. The mixture was diluted to volume of $100 \mathrm{~mL}$, and mixed well. After 10 min, the solution passed through the $C_{18}$ cartridge at a flow rate of $20 \mathrm{~mL} / \mathrm{min}$. The colored chelate would be retained on the cartridge. After the enrichment had finished, the retained chelates was eluted from the cartridge with $2.0 \mathrm{ml}$, of ethanol at a flow rate $5 \mathrm{ml} / \mathrm{min}$ in reverse direction, and the eluent was adjusted to the accurate volume of $2.0 \mathrm{ml}$. in a $2.0 \mathrm{ml}$. calibrated flask by adding microamount of ethanol with a $500 \mu \mathrm{l}$. syringes. The absorbance of this solution was measured at $590 \mathrm{~nm}$ in a $1 \mathrm{~cm}$ cell against a reagent blank prepared in a similar way without vanadium.

\section{Results and Discussion}

Absorption spectra. The absorption spectra of QADEAP and its $V(V)$ complex under the optimum conditions are shown in Figure 1. The absorption peaks of QADГAP and its complex at $\mathrm{pH} 3.5$ are located at $468 \mathrm{~nm}$ and $590 \mathrm{~nm}$.

Effect of acidity. Results showed that the optimal $\mathrm{pH}$ for the reaction of $V(V)$ with QADГAP is 2,2-4,0. A citric acidsodium hydroxide buffer solution of $\mathrm{pH} 3.5$ was recommended to control $\mathrm{pH}$. As the use of $3.5-7.0 \mathrm{~mL}$ of the buffer solution ( $\mathrm{pH} 3.5$ ) per $100 \mathrm{~mL}$ of final solution was found to give a maximum and constant absorbance. The use of $5.0 \mathrm{~mL}$ buffer solution was recommended. The buffer solution containing $0.08-0.15 \mathrm{~mol} / \mathrm{L}$ of $\mathrm{Na}_{2}$ ED' $\mathrm{LA}$ and $0.4-$ $0.6 \mathrm{~mol} / \mathrm{L}$ of $\mathrm{NH}_{4} \mathrm{~F}$ could markedly increase the selectivity of this system. (Without $\mathrm{Na}_{2} \mathrm{ED}$ lA and $\mathrm{NH}_{4} \mathrm{~F}$ in the buffer solution, the tolerance limits of foreign ions were $0.01 \mathrm{mg}$ for Cu(II), Fe(III), $\angle \mathrm{n}($ II); $0.005 \mathrm{mg}$ for Sn(IV), Pd(II), $\mathrm{Co}(\mathrm{ll})$. $\mathrm{Ni(l])}$. However, the tolerance limits of foreign ions reached $3 \mathrm{mg}$ for $\mathrm{Fe}(\mathrm{III}) ; 0.3 \mathrm{mg}$ for $\mathrm{Cu}(\mathrm{II}), \mathrm{Kn}(\mathrm{II}) ; 0.1 \mathrm{mg}$ for Co(II), Ni(II), Sn(IV); 0.05 mg for Pd(II) when Na.ED'IA

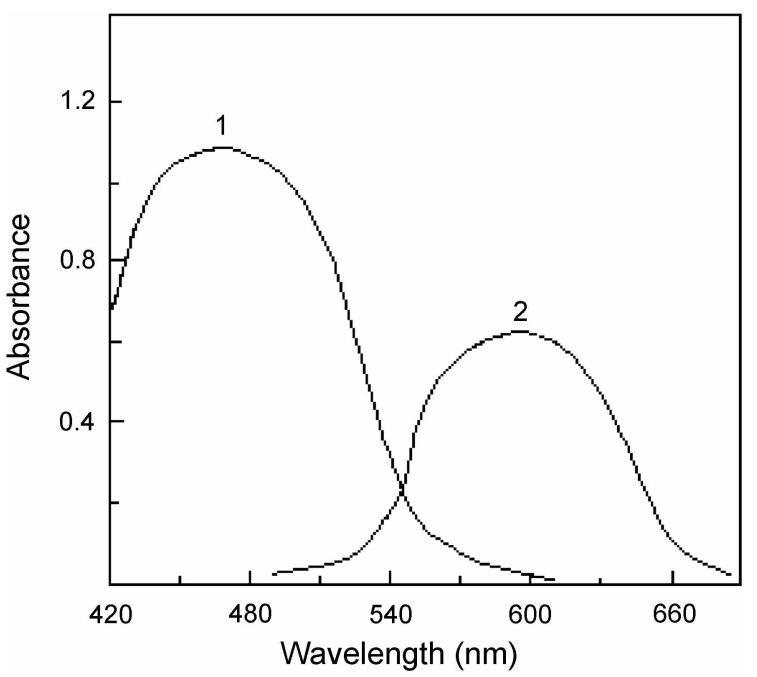

Figure 1. Absorption spectra of $Q \Lambda D E \wedge P$ and its V(V) complex: I QADEAP-CTMAB blank against water. 2 QADEAP-V(V)(IMAB complex against reagent blank.

and $\mathrm{NH}_{4} \mathrm{~F}$ existed in the buffer solution). Therefore, $0.1 \mathrm{~mol} / \mathrm{l}$. of $\mathrm{Na}_{2}$ Г.DTA and $0.5 \mathrm{~mol} / 1$. of $\mathrm{NH}_{4} \mathrm{~F}$ in the buffer were recommended.

Effect of surfactants. The V(V)-QADEAP complex has a poor solubility in water solution. It is need to add a suitable amount of surfactants to enhance the solubility of the complex. Fxperiments showed that all the anionic surfactants, nonionic surfactants and cationic surfactants have good effect to enhance the solubility. In addition to enhance the solubility, in the nonionic surfactants and cationic surfactants medium, the sensitivity of the V(V)-QADГ:AP chelates was increased markedly too. The effect of the nonionic surfactants and cationic surfactants improving the sensitivity is shown in Table 1 . The results show that CTMAB was the best additive and the use of 2.0-5.0 ml. of CTMAB gives a constant and maximum. Accordingly, $3.0 \mathrm{~mL}$. CTMAB solution was recommended.

Effect of QADEAP concentration. For up to $1.2 \mu \mathrm{g}$ of $\mathrm{V}(\mathrm{V})$, the use of about $5 \mathrm{~mL}$ of $1.0 \times 10^{-4} \mathrm{~mol} / \mathrm{L}$ of QADEAP solution has been found to be sufficient for a complete reaction. Accordingly, $5.0 \mathrm{~mL}$ of QADEAP solution was added in all further measurement.

Stability of the chromogenic system. After mixing the components, the absorbance reaches its maximum within 10 $\mathrm{min}$ at room temperature and remains stable for at least $16 \mathrm{~h}$. When extracted into the ethanol medium, the chelate can keep stable at least $12 \mathrm{~h}$.

Solid phase extraction. Both the enrichunent and the elution were carried out on a Waters SPE device (It is able to prepare twenty samples simultaneously). 'The flow rate was set to $20 \mathrm{~mL} / \mathrm{min}$ for enrichment and $5 \mathrm{~mL} / \mathrm{min}$ for elution.

Table 1. The effect of surfactants on V(V)-QADEAP chromogenic system

\begin{tabular}{cccccccc}
\hline Surlactanl & Absence & (IMAB & CPI3 & TritonX-100 & Fmulsilier-()P & Tiween-80 & Tiween-20) \\
\hline$\lambda_{\max }(\mathrm{nm})$ & 584 & 590 & 590 & 586 & 586 & 586 & 586 \\
$\varepsilon\left(\times 10^{+}\right) 1 \mathrm{~mol}^{-1} \cdot \mathrm{cm}^{-1}$ & 8.85 & 12.8 & 11.2 & 9.17 & 8.92 & 9.22 & 8.76 \\
\hline
\end{tabular}


Some experiments were carried out in order to investigate the retention of QADEAP and its V(V) chelate on the cartridge. It was found that the QADEAP and its V(V) chelate could be retained on cartridge quantitatively when they pass the cartridge as aqueous solution. The capacity of the cartridge for QADEAP was $18 \mathrm{mg}$ and for its V(V) chelate was $16 \mathrm{mg}$ in a $100 \mathrm{~mL}$ of solution. In this experiments. the cartridge has adequate capacity to enrich the V(V)-QADEAP chelate and the excess QADEAP.

In order to choose a proper eluent for the retained QADEAP and its V(V) chelate. various of organic solvents were studied. It was found that the tetrahydrofuran. acetone. acetonitrile. ethanol and methanol could elute the QADEAP and its $V(V)$ chelate from cartridge quantitatively. The ethanol has a low volatility. toxicity and price, so ethanol was selected as eluent. Experiment show that it was easier to elute the retained QADEAP and its V(V) chelate in reverse direction than in fonvard direction. so it is necessary to upturned cartridge during elution. $2.0 \mathrm{~mL}$ of ethanol was sufficient to elute the QADEAP and its V(V) chelate from cartridge at a flow rate of $5 \mathrm{~mL} / \mathrm{min}$. The volume of $2.0 \mathrm{~mL}$ eluent was used in this experience.

Calibration curve and sensitivity. The calibration curve shown that Beer's law is obeyed in the concentration range of $0.01-0.6 \mu \mathrm{g} \mathrm{V}(\mathrm{V})$ per $\mathrm{mL}$ in the measured solution. The linear regression equation obtained was: $\mathrm{A}=2.512 \mathrm{C}(\mu \mathrm{g} /$ $\mathrm{mL})+0.0206,(\mathrm{r}=0.9994)$. The molar absorptivity was

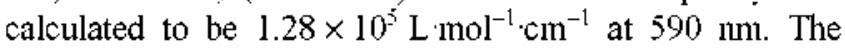
relative standard deviation at a concentration level of $0.04 \mu \mathrm{g}$ of $V(V)$ per $\mathrm{mL}$ (11 repeat determination) was $1.68 \%$. The detection limit is $0.04 \mu \mathrm{g} / \mathrm{L}$ in original samples.

Composition of the complex. The composition of the complex was deternined by continuous variation and molar ratio method. Both showed that the molar ratio of $V(V)$ to QADEAP is $1: 2$.

Interference. The selectivity of the proposed method was investigated by the determination of $1.0 \mu \mathrm{g} / 100 \mathrm{~mL} \mathrm{V(V)} \mathrm{in}$ the presence of various ions within a relative error of $\pm 5 \%$.
Table 2. Tolerance limits for the detemmination of $1.0 \mu \mathrm{g}$ of $\mathrm{V}(\mathrm{V})$ with QADEAP (Relative error $\pm 5 \%$ )

\begin{tabular}{|c|c|}
\hline Ion added & $\begin{array}{c}\text { Tolerate } \\
\text { (mg) }\end{array}$ \\
\hline $\mathrm{NO}_{3}^{-}, \mathrm{K}^{+}$, borate, tartaric acid & 80 \\
\hline $\mathrm{Li}^{+}, \mathrm{Al}^{3+}, \mathrm{PO}_{4}{ }^{3-}, \mathrm{SO}_{4}{ }^{7-}, \mathrm{ClO}_{4}^{-}$, oxalic acid, $\mathrm{CO}_{3}{ }^{3-}, \mathrm{ClO}_{4}^{-}$ & 20 \\
\hline $\mathrm{Ca}^{2+}, \mathrm{Mg}^{2+}, \mathrm{SO}_{3}^{2-}, \mathrm{Sr}^{2-}, \mathrm{Ba}^{2+}, \mathrm{IO}_{3}^{-}, \mathrm{BrO}_{3}^{-}, \mathrm{B}(\mathrm{IL}), \mathrm{ClO}_{3}^{-}, \mathrm{Fe}^{3+}$ & 3 \\
\hline $\mathrm{Mn}^{2+}, \mathrm{Ce}(\mathrm{IV}), \mathrm{W}(\mathrm{WI}), \mathrm{Mo}(\mathrm{VI}), \mathrm{Cr}^{3-}, \mathrm{Fe}^{2^{-}}$ & 1 \\
\hline Ti(IV), Bi(III), Cr(VI), $\mathrm{Zr}(\mathrm{IV}), \mathrm{Zn}^{1^{+}}, \mathrm{Cu}^{2-}$ & 0.3 \\
\hline $\mathrm{Tl}$ (III), $\mathrm{Cd}^{1^{+}}, \mathrm{La}^{3+}, \mathrm{Sn}(\mathrm{IV}), \mathrm{Co}^{2+}, \mathrm{Ni}^{2^{++}},\left(\mathrm{Pt}(\mathrm{IV})^{*}, \mathrm{Ag}^{+*}\right)$ & 0.1 \\
\hline Kứ(II) $, \mathrm{Bi}(\mathrm{III}), \mathrm{Pb}^{1+}, \mathrm{Hg}^{{ }^{7+}}, \mathrm{Sb}^{3+}, \mathrm{Pd}^{1}, \mathrm{Os}(\mathrm{VIII})$ & 0.05 \\
\hline Se(IV), Te(IV), $\mathrm{All}^{3+}, \mathrm{S}_{2} \mathrm{O}_{3}^{2-}, \mathrm{Zr}$ (IV), Th(IV) & 0,02 \\
\hline $\operatorname{Ir}(\mathrm{IV}), \operatorname{Rh}(\mathrm{III}), \operatorname{Ru}(\mathrm{III}), \mathrm{U}(\mathrm{IV})$ & 0.01 \\
\hline Pt(IV), $\mathrm{Ag}^{+}$ & 0.005 \\
\hline
\end{tabular}

*masking with $\mathrm{NH}_{4} \mathrm{SCN}$.

The results are given in Table 2. Results show that $\mathrm{Ag}(\mathrm{I})$, $\mathrm{Pt}(\mathrm{IV})$ gives a serious interfere. These interferes can be eliminated by mask with $\mathrm{NH}_{4} \mathrm{SCN}$. This method is highly selective.

Application. The proposed method has been successfully applied to the determination of vanadium( $(V)$ in biological samples and water samples.

For biological samples. $0.20 \mathrm{~g}$ of sample was weighted accurately into the Teflon high-pressure microwave acid digestion bomb (Fei Yue Analytical Instrument Factory, Shanghai. China) $2.5 \mathrm{~mL}$ of concentrated nitric acid and 2.5 $\mathrm{mL}$ of $30 \%$ hydrogen peroxide were added. The bombs were sealed tightly and then positioned in the carousel of the microwave oven (Model WL 5001, 1000 W. Fei Yue Analytical Instrument Factory, Shanghai, China). The system was operated at full power for $6.0 \mathrm{~min}$. The digest was evaporated to near dryness. The residue was dissolved with $1 \%$ of hydrochloric acid. and the vanadium( $(V)$ contents were analyzed according to general procedure. The results are shown in Table 3.

For water sample, the samples were filtrated by $0.45 \mu \mathrm{m}$

Table 3. Detenmination of vanadium in certified standard biological samples

\begin{tabular}{clcc}
\hline Sample & \multicolumn{1}{c}{ Standard value $(\mu \mathrm{g} / \mathrm{g})^{2}$} & $\begin{array}{c}\text { This method } \\
(\mu \mathrm{g} / \mathrm{g})\end{array}$ & $\begin{array}{c}\text { RSD, \% } \\
(n=5)^{\prime \prime}\end{array}$ \\
\hline $\begin{array}{c}\text { Humant hair } \\
\text { (GBW07601) }\end{array}$ & $\mathrm{As}(0.28), \mathrm{Bg}(1.3), \mathrm{Bi}(0.34), \mathrm{Ca}(2900), \mathrm{Cd}(0.11), \mathrm{Ce}(1.2), \mathrm{Co}(0.71), \mathrm{Cr}(0.37), \mathrm{Cu}(10.2), \mathrm{Fe}(54)$, & 1.81 \\
\hline Tea Leaf & $\mathrm{As}(0.191), \mathrm{Ba}(15.7), \mathrm{Ca}(2840), \mathrm{Cd}(0.032), \mathrm{Co}(0.2), \mathrm{Cr}(0.8), \mathrm{Cu}(16.2), \mathrm{Fe}(373), \mathrm{Hg}(0.004)$, & 3.05 & 2.1 \\
(GBW08505) & $\mathrm{Mg}(2240), \mathrm{Mn}(766), \mathrm{Ni}(7.61), \mathrm{V}(3.12), \mathrm{Pb}(1.06), \mathrm{Se}(0.041), \mathrm{Zn}(38.7)$ & \\
\hline
\end{tabular}

"Arerage of tive times determination results. ${ }^{b}$ RSD was obtained from the detemination of the same samples for 5 times.

Table 4. Detemination of vanadium in water samples

\begin{tabular}{|c|c|c|c|c|}
\hline \multirow{2}{*}{ Samples } & \multicolumn{2}{|c|}{ Van1adium Found (ng/mL) } & \multirow{2}{*}{$\begin{array}{l}\text { RSD\% } \\
(\mathbb{N}=5)^{b}\end{array}$} & \multirow{2}{*}{ Average recovery $\%$} \\
\hline & The Proposed Method ${ }^{\sigma}$ & ICP-MS Method & & \\
\hline Panlong River Water & 32.1 & 35.4 & 2.1 & 97 \\
\hline Diangci Lake Water & 43.2 & 44.5 & 2.3 & 102 \\
\hline Kurming Tap Water & 26.5 & 23.8 & 2.4 & 98 \\
\hline
\end{tabular}

"Average of five times determination results. "RSD was obtained from the detenmination of the same samples tor 5 times. 
filter, and the vanadium(V) contents were analyzed according to the general procedure. The results were shown in Table 4 . together with the results of a recovery test by adding $0.2 \mu \mathrm{g}$ of vanadium( $(\mathrm{V})$ in samples. A standard method using ICP-MS has also been used as reference method. The results are also shown in Table 4.

\section{Conclusion}

This method is highly selective and highly sensitive. QADEAP is one of the sensitive and selective spectrophotometric reagents for vanadium. The molar absorptivity of the chelate reaches $1.28 \times 10^{5} \mathrm{~L}^{-1} \mathrm{~mol}^{-1} \mathrm{~cm}^{-1}$ in measured solution. Most foreign ions do not interfered with the determination when masked with $\mathrm{Na}_{2} \mathrm{EDTA}$ and $\mathrm{NH}_{4} \mathrm{~F}$. By solid phase extraction with $\mathrm{C}_{18}$ cartridge. the QADEAP-V(V) chelate in $100 \mathrm{~mL}$ solution can be concentrated to $2.0 \mathrm{~mL}$. The detection limit is $0.04 \mu \mathrm{g} / \mathrm{L}$ in original samples. and $\mu \mathrm{g} / \mathrm{L}$ level of vanadium in water can be determined with good results. The consuming of organic solvents in this method is much lower than those consumed in liquid-liquid extraction method. Because ethanol has a lower volatility and toxicity. this method is more safe than those method using other organic solvents. By using Waters SPE device twenty samples can be prepared simultaneously. This method is rapid for simultaneously preparing large amount of sample.

Acknow ledgement. The project was supported by Natural Science Foundation of Yunnan Province (0111143)

\section{References}

1. Henk. H. G.: Jaap. B.: Gerard. V. K. Chemical Societu Review's 2002. $31(6) .357-364$.

2. Hogan. G. R. Bulletin of Entionmental Contantination and Toxicology 2000. 6+(4), 606-610.

3. Agnihotri, N.: Dass. R; Melita, J. R. (hemical Analvsis (Harsan) $4(4) .418-425$.

4. Costa. A. C. S.: Teineira. L. S. Q.: Jaeger. H. V.: Ferreira. S. L. C. Mikrochimica Acta 1998. 130.41-45.

5. Yang. G. Y: Yin. J. Y: Liu. M.: Hu. Q. H. Chinese Journal of Anatical Chentistry (Fenxi Huante) 1999, 27(1). 10-13.

6. Starezewska. B. Jomnal of Trace and Michoprobe Techiques 2002. 20(3). 377-384.

7. Melwanki. M. B.: Seetharamappa. T.: Masti. S. Analvical Sciences 2001. 17(8). 979-982

8. Zhou. S. P.: Yang, G. Y.: Yin. J. Y.: Wu. C. H. Chmese Joumal of Anafutical Chentisty (Fenxi Htante) 2000, 28(7), 890-892.

9. Safavi. A.: Nezhad. M. R. Analyica Chimica .Acta 2002. 9(1:2). 283-289.

10. Gavazov. K.: Simeonova. Z. H.: Alesandrov. A. Talanta 2000. $52(3) .539-544$

11. Miura J : Hoshion. H.: Yotsuyanagi. T. Anatytical Chintica Acta 1990. 233, 121-127.

12. Ishizuki, $T$ : Tsuzuki. M: Yuchi, A: Ozawa. T: Wada. H: Nakagawa. G. Analutica Chinica Acta 1993. 272. 161-165.

13. Yang. G. Y.: Hu. Q. F.: Yang. J. H.: Huang. Z. J.: Yin. J. Y. Analutical. Sciences 2003. 19(2). 299-303.

14. Simgh. I.: Poonam, M. Talamta 1984. 31. 109-114.

15. Hu. Q. H.; Yang, G. Y.: Huang. Z. J.; Yin. J. Y. Talama 2002, 58. 467-473.

16. Hu. Q. F.: Yang. G. Y.: Yang. T. H.: Yin. J. Y. Jownal of Enironnent Honitoring 2002. $4(6) .956-959$. 